\title{
Efektivitas "Cognitive Behavior Therapy" terhadap Penurunan Derajat Stres
}

\author{
UMAR YUSUF, ${ }^{1}$ R. LUKI SETIANTO² \\ 1,2 Fakultas Psikologi, Unisba, Jl.Tamansari No.1, Bandung 40116 \\ email: ${ }^{1}$ kr_umar@yahoo.co.id
}

\begin{abstract}
Effectivity of Cognitive Behavior Therapy to decrease degree of stress in patients with chronic Low Back Pain(LBP). Chronic LBP can be psychogenic that arise secondary to frustrated patients facing illness and contribute to disease exacerbation. It is the result of individual cognitive processing associated with stress on individual self. This study was how the influence of CBT can help reduce the degree of stress Respondents in this study were two patients with chronic LBP. Based on the research results can be concluded that Cognitive Behavior Therapy is empirically shown to decrease influence in the degree of stress in patients with chronic Low Back Pain in Hospital $X$ of Bandung City.
\end{abstract}

Keywords: low back pain, degree of stress, cognitive behavior therapy.

Abstrak. Efektivitas Cognitive Behavior Therapy terhadap penurunan derajat stres pada pasien penderita Nyeri Punggung Bawah (NPB) kronik. NPB kronik dapat bersifat fisik maupun psikogeni. NPB yang bersifat psikogenik merupakan hasil dari pengolahan kognitif yang dihubungkan dengan stress. Penelitian ini dilakukan untuk mendapatkan gambaran mengenai bagaimana pengaruh CBT dapat membantu menurunkan derajat stres pada pasien NPB kronik di RS ' $X$ ' kota Bandung. Berdasarkan hasil penelitian dapat disimpulkan bahwa Cognitive Behavior Therapy secara empirik terbukti memberikan pengaruh pada penurunan derajat stres pada kedua pasien NPB kronik di RS ' $X$ ' kota Bandung.

Kata kunci: Nyeri punggung bawah, derajat stress, kognitif behavior terapi.

\section{Pendahuluan}

Nyeri punggung bagian bawah yang kronik adalah suatu perasaan nyeri yang berkelanjutan yang biasanya telah berlansung lebih dari 3 bulan, dan biasanyapermasalahan lebih kompleks, sehingga lebih sulit untuk ditangani, atau diberi pengobatan ataupun dilakukan pengendalian. Meskipun sudah banyak usaha-usaha yang dilakukan terhadap pasien untuk mengatasi keluhan-keluhan rasa nyerinya. Namun seringkali pasien tetap mengeluh atas penderitaannya. Oleh karena itu para neurolog sering menghubungkan rasa nyeri ini lebih bersifat yellow flags atau berkaitan dengan aspek-aspek psikis dari pasien.

Berangkat dari fenomena tersebut, penulis tertarik melakukan studi awal terhadap beberapa pasien penderita nyeri punggung bagian bawah ini dengan melakukan wawancara terhadap empat orang pasien penderita nyeri punggung bagian bawah kronik ini di Rumah Sakit " $X$ " yang berada di wilayah kota Bandung. Responden pertama berinisial A, usia 37 tahun, seorang karyawan dari perusahaan swasta, kurang lebih 6 bulan yang lalu dia didiagnosis mengalami keluhan nyeri punggung bagian bawah yang bersifat kronis. A sebenarnya memiliki riwayat nyeri pinggang akut pada satu tahun yang lalu, namun beberapa bulan terakhir dia mengeluhkan kembali rasa nyerinya yang sangat hebat dan tak juga kunjung membaik. Selanjutnya, pasien B, seorang laki-laki berusia 57 tahun, pensiunan PNS, memiliki riwayat nyeri pinggang akut (cedera otot saat berolah raga) beberapa tahun yang lalu. Namun rasa nyeri dibagian pinggang ini kembali kambuh beberapa bulan belakangan terutama setelah memasuki masa persiapan pesiun.

Pasien C ( $L, 42$ tahun) seorang anggota TNI, memunyai riwayat cedera pada bagian pinggangnya saat menjalani penugasan. Dengan kondisi fisik yang dialaminya menurut $C$ sangat sulit baginya untuk mengikuti kegiatan-kegiatan yang memanfaatkan kondisi fisiknya seperti 
sediakala sebelum ia mengalami nyeri punggung. Selanjutnya, pasien berinisial "D" seorang perempuan usia 42 tahun, pekerjaan ibu rumah tangga, yang mengalami nyeri punggung bawah sejak satu tahun yang lalu. Menurut $D$ rasa nyeri tersebut seringkali muncul dan meningkat intensitasnya disaat dia mengerjakan tugas-tugas rumah tangga sehari-hari.

Intensitas munculnya rasa nyeri yang terjadi pada pasien dengan keluhan nyeri punggung kronik ini, ternyata memiliki keterkaitan dengan munculnya pikiran-pikiran irasional atas permasalahan yang dihadapinya, terutama yang terkait dengan adanya perasaan tertekan atas situasi yang dihadapinya. Hal ini tentunya terkait dengan apa yang disebut penilaian kognitif (cognitive appraisals) terhadap situasi-situasi yang mendatangkan stres. Situasi stres yang dialaminyasecara tidak sadar dialihkan ke dalam bentuk nyeri punggung bagian bawah. Nyeri punggung kronik adalah rasa nyeri fisik yang kemunculannya secara terus menerus dan menciptakan penderitaan atas rasa nyerinya, yang selanjutnya mempengaruhi keterbatasannya dalam hal aktivitas personal, sosial, dan kerja. Walaupun faktor-faktor tersebut telah diketahui sejak dahulu, namun baru setengah abad ini dilakukan pendekatan sistematik dengan menggabungkan model pendekatan yang komprehensif untuk memahami berbagai faktor mendasari munculnya rasa nyeri (Melzack \& Casey, 1968; Melzack \& Wall, 1965 dalam Turk \& Gatchel, 2002).

Nyeri punggung bagian bawah (NPB) adalah perasaan nyeri yang dirasakan di daerah punggung bagian bawah, yang kemungkinan dapat merupakan rasa nyeri lokal maupun rasa nyeri radikuler atau keduanya. Rasa nyeri yang dirasakan biasanya sepanjang tungkai yang melewati lutut, dan rasa sakit bisa sampai ke ujung kuku, atau disebut denganiskhialgia. Nyeri yang berasal dari daerah punggung bagian bawah ini dapat menjalar ke daerah lain, atau sebaliknya di mana rasa nyeri yang berasal dari daerah lain dirasakan di area punggung bawah (referred pain). Namun demikian, penyebaran rasa nyeri inijuga disebabkan oleh kelainan pada muskuloskeletal, atau sistem saraf atau dapat juga dikarenakan oleh karena faktor stres.

Stres adalah suatu keadaan ketidakseimbangan yang terganggu, di mana orang yang mengalaminya dikatakan di bawah tekanan (understress) (Walter Cannon, 1932 dalam Lazarus, 1984). Stres yang mengganggu keseimbangan dapat disebabkan oleh karena luka fisik atau dapat berupa segala jenis penyakit yang diderita atau karena gangguan emosional (Wingate dalam Tom Cox, 1978: 2). Stres merupakan respon fisiologis individu yang bersifat umum terhadap tuntutan-tuntutan dari luar/lingkungan (Hans Selye, dalam Sarafino, 1990).

Sarafino (1990), menjelaskan bahwa stressor dapat menimbulkan kondisi ketegangan (strain) pada beberapa aspek dalam diri individu. Strain yang dialami dapat muncul dalam beberapa bentuk reaksi biologis dan psikososial. Adapun dampak stres terhadap aspek biologis, dapat terjadi ketika individu dihadapkan pada suatu pengalaman yang dipersepsi sebagai suatu hal yang membahayakan bagi dirinya, maka reaksi tubuh dari individu tersebut akan tergerak dan termotivasi untuk melakukan pertahanan diri. Reaksi tubuh untuk melakukan sistem pertahanan diri ini dilakukan melalui proses perangsangan terhadap kelenjar adrenalin oleh sistem saraf simpatis untuk mensekresikan epinephrine (Cannon, 1929, dalam Sarafino, 1990: 79). Pensekresian zat ini menyebabkan meningkatnya kinerja organ tubuh yang dapat dilihat dalam bentuk peningkatan denyut jantung dan pernafasan, sehinggamemunculkan ketegangan pada otot tubuh, sehingga keringat berlebihan, dan sebagainya.J ika stressor yang dihadapi kuat dan berlangsung lama, maka hal ini dapat menimbulkan dampak terhadap tingkat kerawanan kesehatan yang dinamakan dengan diseases of adaptation, yang mencakup permasalahan kesehatan seperti tekanan darah tinggi, asma, nyeri dan kaku serta masalah kesehatan lain sebagai akibat terganggunya fungsi individu (Selye, dalam Sarafino, 1990).

Selain itu, dampak dari stres,dapat memengaruhi kondisi fisik, dan juga dapat menimbulkan perubahan terhadap kondisi psikologis dan sosial individu. Aspek psikologis yang mudah dipengaruhi stres ini antara lain meliputi aspek kognisi (terganggunya daya ingat serta atensi individu dalam aktivitas kognisinya (Cohen, Evans, Stokols, \& Krantz 1986, dalam Sarafino 1990); pencarian informasi serta evaluasi menjadi tidak efektif (J anis \& Mann, 1977, dalam Lazarus \& Folkman 1986, dalam Sarafino 1990), emosi (rasa takut (fear), kecemasan (anxiety), depresi, serta kemarahan (anger) (Sarafino, 1990). Sedangkan aspek sosial dalam bentuk perilaku sosial individu terhadap lingkungannya (menarik diri dan atau menghindari interaksi sosial dengan lingkunganya.

Upaya untuk menurunkan stres yang disebabkan oleh faktor psikologis adalah melalui Cognitive Behavior Therapy. Cognitive Behavior Therapy adalah sebuah psikoterapi yang menekankan pentingnya peranan kognitif terhadap apa yang kita rasakan dan lakukan. CBT menggunakan pendekatan Biopsikososial. Pendekatan biopsikososial ini mencakup peranan fungsi otak (pada setiap individu) yang memengaruhi aktivitas mental (proses kognitif- 
konstruktif) dan faktor lingkungan yang berperan sebagai eksternal (social) stimulus yang ikut berperan membangun core beliefs, values, dan goals individual.

Cognitive Behavior Therapy / CBT adalah terapi yang memfokuskan pada bagaimana mengubah pemikiran atau keyakinan yang negatif (Beck, 1995). CBT tujuannya adalah membantu seseorang untuk memecahkan permasalahan mengenai disfungsi emosional, perilaku dan kognisi secara sistematis. CBT percaya bahwa klien akan berubah bila mereka belajar untuk berpikir secara berbeda, oleh karena itu, terapis CBT lebih memfokus diri pada upaya mengajarkan keterampilan self-counseling yang rasional (dalam Yusuf, Umar \& Patresia, Raisa. Jurnal Intervensi Psikologi. Vol 3. No 2. 2011).

Karakteristik CBT didasari pada model kognitif dari respons emosional. Dari fakta-fakta ilmiah menunjukkan bahwa pikiran kita menimbulkan perasaan dan perilaku, bukan sebaliknya di mana faktor eksternal mempengaruhi perasaan dan pikiran kita. Keuntungan dari model kognitif ini: (a) kita dapat mengubah cara kita berpikir agar merasakan dan bertindak lebih baik meskipun suasananya tidak berubah; (b) CBT adalah singkat dan dibatasi waktu. Rata-rata diperlukan 12 sessi (across all types of problems) - yaitu untuk mengatasi problem yang dihadapi saat ini dan apa yang ingin dicapai 1, 2, 4, 8, 12 minggu kedepan. Yang membuat $C B T$ singkat adalah analisa fungsional yang menentukan kekuatan dan kelemahan klien serta skills training yang terstruktur dan task assignment (exercises). (c) CBT fokus pada keprihatinan klien dan pada kelemahannya; (d) Therapeutic Relationship penting tetapi bukan menjadi fokus. Memang hubungan positif dapat menimbulkan kepercayaan, tetapi hal itu bukan fokus CBT. CBT percaya bahwa klien akan berubah bila mereka belajar untuk berpikir secara berbeda, maka terapis CBT fokusnya pada mengajar keterampilan self - counseling yang rasional; (e) CBT merupakan usaha secara kolaboratif antara klien dan terapis. Terapis melakukan assessment untuk mengetahui apa yang ingin dicapai dalam hidup mereka (goals) dan membantu mereka mencapainya. Peranan terapis adalah mendengarkan, mengajarkan, dan mendorong (encourage), dimana peranan klien adalah mengeksperikan keprihatinannya, belajar, dan mengimplementasikan apa yang dipelajari: (f) CBT menggunakan metode Socratic. Terapis $C B T$ ingin mendapatkan apa yang menjadi keprihatinan (concern) klien secara tepat yang selalu diverifikasi. Maka terapis selalu mengajukan pertanyaan, tetapi bukan pertanyaan yang mengulang. Tetapi menggunakan cara bertanya seperti dilakukan Socratic; (g) CBT terstruktur dan terarah. Artinya setiap pertemuan dalam agenda intervensi, telah ditetapkan secara spesifik, khususnya dalam membahas setiap keprihatinan yang dirasakan oleh klien. Teknik atau konsep yang diberikan selama pertemuan adalah mengajak pasien untuk berpikir rasional tentang rasa keprihatinan klien. Fokus dan tujuan intervensinya ditetapkan bersama-sama (pasien dan terapis), dan aktivitas yang dilakukan terarah (directive) pada tujuan-tujuan yang ingin diselesaikan klien. Oleh karena ituterapis $C B T$ tidak mengatakan apa yang harus dilakukan, tetapi mengajarkan apa yang belum diketahui klien dan bagaimana melakukannya; (h) CBT diturunkan berdasarkan sebuah model pembelajaran. Artinya CBT didasarkan atas scientific support atas setiap reaksi perilaku yang telah dipelajari. Oleh karena itu, tujuan terapi adalah membantu klien belajar kembali atau (relearn). Di mana apa yang dipelajari adalah belajar menghindari reaksi yang tidak diinginkan dan selanjutnya belajar cara baru untuk bereaksi yang tepat atas permasalahan yang dihadapi. Sehingga dasar teoritis yang digunakan adalah memanfaatkan teori client centered dari Carl Roger. Adapun model pembelajarannya adalah metode edukasi untuk mengarahkan hasil jangka panjang (transferring perceptual to procedural); (i) Teori dan teknik CBT bergantung pada inductive model. Di mana aspek yang menjadi pusat perhatiannya adalah berpikir rasional yaitu berdasarkan fakta bukan hanya berdasarkan asumsi (maka verifikasi dalam proses terapi selalu dilakukan). Misalnya 'kita kesal akan sesuatu, meskipun faktanya situasi tersebut tidak seperti yang kita pikirkan. Bila kita tahu tentang hal itu, maka kita tidak akan membuang waktu untuk merasa kesal.'

Sedangkan Inductive model yang digunakan adalah mendorong seseorang untuk melihat pikirannya dan mempertanyakan kembali serta menguji pikirannya tersebut (meta thinking); (j) Assignment dan homework merupakan elemen pokok bagi CBT. Assignment dan homework merupakan proses pelatihan (pengulangan) agar dapat menjadi procedural knowledge (implicit, tacit). Di mana dalam hal ini terapis berfungsi sebagai coach untuk melatih klien menguasai keterampilannya (mastering skills).

Proses Cognitive Behavior Therapy adalah terapi jangka pendek yang terstruktur, di mana terapis membutuhkan untuk memformulasikan tentang pikiran klien dalam kerangka kognitif agar dapat memfasilitasi pemahamannya tentang pola emosi, perilaku dan fisiologis (Beck, Dobson, Leahy, dan Persons, dalam Kazantzis, dalam Otis 2007). Oleh karena itu, jalannya terapi sangat bergantung pada hubungan terapeutik dengan klien yang sangat kuat, di mana dalam hal ini perlunya suatu kolaborasi empiris antara terapis dan klien yang bertujuan untuk memastikan bahwa klien 
mengalami perubahan dalam menuju target terapi dan mencegah terjadinya stres yang merugikan diri klien di masa yang akan datang. CBT biasanya dilakukan dalam jangka pendek (antara 10 sampai 20 pertemuan). Oemarjoedi (2003) bahkan melakukan efisiensi dengan merubah menjadi lima kali pertemuan, dengan tujuan agar dapat diterapkan dengan kondisi lebih baik, khususnya untuk kondisi di Indonesia.

CBT ini merupakan suatu proses atas perubahan perilaku yang diharapkan. Oleh karena itu proses terapi dilakukan dalam bentuk transformasi pengetahuan yang diasosiasi oleh conscious mind ke dalam konsolidasi denganunconscious mind - yang memungkinkan dapat mengingat sewaktu-waktu jika dibutuhkan agar otak dapat mempertahankan pelaksanaan satu tugas pada saat yang bersamaan. Ini merupakan suatu peran dari terapis/ trainer/ ccounselor untuk menerapkan keterampilan(skills) - dari perceptual knowledge ke prosedural knowledge. Oleh karena itu, fungsi CBT dalam intervensi adalah memberikan keterampilan baru dengan pembelajaran ulang, serta mengembangkannya menjadi prosedural (unconscious). Proses terapi akan dimulai dengan melakukan identifikasi atas persepsi klien yang terdistorsi atau atau yang menyebabkan timbulnya masalah pada klien. Beberapa cara untuk melakukan self-defeating sebagaimana yang diidentifikasikan oleh Aaron Beck adalahmengenai pemikiran seperti "semua atau tidak sama sekali' (all-or-nothing), atau dengan melebih-lebihkan atau menyepelekan suatu kejadian, atau melakukan generalisasi yang berlebihan, atau melakukan personalisasi (menanggapi segala sesuatu secara personal), atau melakukan seleksi dengan (tidak memandang suatu kejadian negatif dengan cara yang sepantasnya), atau mengambil kesimpulan yang tidak logis tentang suatu kejadian, dan pemikiranpemikiran yang otomatis (pemikiran yang terusmenerus muncul, seperti "saya tidak bisa melakukan segala hal dengan benar").

Setelah pemikiran-pemikiran negatif ini diidentifikasikan, terapis selanjutnya membantu klien untuk mengganti pemikiran-pemikiran tersebut dengan pemikiran yang lebih adaptif. Proses ini dilakukan dengan melibatkan teknik berulang seperti self evaluation, positive self- talk, control of negative thoughts and feelings, dan selanjutnya melakukan pemeriksaan yang akurat tentang situasi eksternal serta kondisi emosi klien itu sendiri. Klien selanjutnya diminta untuk melatih teknik-teknik itu sendiri, dengan terapis, dan sebisa mungkin klien menerapkan teknik tersebut pada situasi aktual saat berhadapan dengan situasi yang penuh tekanan. Sehingga diharapkan secara bertahap klien dapat meningkatkan kepercayaan diri tentang kemampuan untuk menghadapi dan mengatasi situasi yang sulit dengan cara mengubah pola respon yang disfungsional ke yang fungsional. Asumsi CBT adalah pada saat klien terlibat secara aktif dalam menilik suatu permasalahan, dia berusaha untuk mengaplikasikan hasil belajarnya ke dalam situasi sehari-hari, yang dapat mendatangkan situasistres emosional yang buruk. Sehingga dengan demkian klien dapat dikatakan klien akan dapat memeroleh keuntungan jangka pendek dan jangka panjang dari hasil terapinya (Kazantzis, Deane, Ronan, \& L'Abate, dalam Otis, 2007).

Pendekatan Cognitive-Behavioral telah menjadi konseptualisasi dari nyeri yang paling umumditerima, sebagaimana model tersebut muncul dengan nilai heuristik dalam menjelaskan pengalaman dan respon terhadap nyeri kronik dan akut. Aplikabilitas dari konseptualisasi C-B belum secara seksama diperiksa dalam keadaan nyeri akut, tetapi tidak ada alasan untuk percaya bahwa fitur-fitur yang mendasari model tidak dapat diaplikasikan pada nyeri akut.

CB model memandang bahwa reaksi-reaksi yang dimunculkan oleh individu didasari oleh ekspektasi-ekspektasi yang dipelajari oleh individu. Menurut $C B$ model, faktor yang penting bukanlah peristiwa-peristiwa yang terjadi bersama-sama dalam suatu waktu, melainkan pada bagaimana individu belajar untuk memprediksinya berdasarkan pengalaman dan pemrosesan informasi yang mereka terima. Informasi-informasi yang mereka terima, mereka saring dengan pengetahuan-pengetahuan yang mereka miliki dan bereaksi berdasarkannya. Konsekuensinya, respon mereka bukanlah berdasarkan pada realitas objektif, melainkan pada interpretasi-interpretasi yang bersifat subjektif terhadap realitas (Turk, 2002).

Nyeri adalah persepsi subjektif yang merupakan hasil dari transduksi, trasmisi, dan modulasi dari input sensori yang disaring melalui komposisi genetik seseorang dan learning history sebelumnya serta dimodulasi lebih lanjut oleh keadaan psikologis saat ini, penilaian idiosyncratic, ekspektasiekspektasi, keadaan mood saat ini, dan lingkungan sosiokultural seseorang (Turk \& Monarch dalam Turk $\&$ Gatchel, 2002).

Berdasarkan kerangka teoritis yang dikemukakan maka hipotesis yang diturunkan adalah "Pemberian intervensi $C B T$ efektif untuk menurunkan derajat stress pada pasien NPB kronik di Rumah Sakit ' $X$ ' kota Bandung."

Desain penelitian yang digunakan adalah kuasi eksperimental dengan pretest and posttest design (one grup pretest dan posttest design). Design ini menggunakan dua kali pengukuran sebelum treatment dan sesudah treatment diberikan (Hatta, dalam Mimbar Vol 29. No 1, 2013. Ciri utama dari desain one group adalah 
bahwa suatu kelompok dibandingkan dengan dirinya sendiri. Pada desain ini suatu kelompok diukur sebanyak dua kali (YI, Y2) sebelum diberikan treatment, atau biasa disebut sebagai pretest. Kemudian diberikan treatment untuk mengubah variabel terikat tersebut $(\mathrm{X})$. Setelah treatment, dilakukan lagi pengukuran terhadap variabel terikat dari kelompok yang diukur (Y3) atau biasa disebut sebagai posttest. Hasil dari pengukuran tersebut akan dibandingkan untuk melihat perubahan yang terjadi dari pengukuran sebelum dan sesudah treatment (Yusuf dan Patriasia, dalam Jurnal intervensi Psikologi. Vol 3. No 2. 2011).

Adapun analisis data yang dilakukan adalah melalui penilaian dan pengukuran sebelum terapi yang dilakukan untuk mengetahui bagaimana pola distorsi kognitif yang dialami oleh pasien NPB kronik kemudian akan diperbandingkan dengan hasil penilaian selama proses terapi berlangsung, apakah subyek mampu menghasilkan alternatifalternatif pemikiran baru dari yang semula negatif menjadi lebih positif. Pencatatan dan pengukuran selama terapi mengacu pada hasil identifikasi distorsi kognitif yang telah disusun pada awal terapi. Berdasarkan perbandingan tersebut kemudian dibuat deskripsi dan dinamika dari setiap subyek mengenai stres dan distorsi kognitif yang dialaminya dengan dibantu oleh data-data penunjang lainnya.

\section{Sasaran Terapi}

Pada Tabel 1 adalah hasil dari analisis sasaran terapi yang penyusunannya didasarkan pada analisa fungsional dari kedua pasien NPB kronik.

Adapun penjelasan dari asumsi adalah kekuatan atau kelemahan yang didasari atas evaluasi diri, sedangkan yang dimaksud aturan di sini adalah aturan pribadi yang dibuat untuk memfasilitasi asumsi, dan sikap adalah sikap yang yang dipilih sehubungan dengan core beliefnya. Dalam analisis sasaran ini perubahan asumsi, aturan, dan sikap diarahkan dari yang lama ke yang baru sehingga diharapkan terjadi perubahan menjadi lebih baik, dan tentunya dapat memberi pengaruh bagi terbentuknya keyakinan diri yang baru.

Berikut ini adalah hasil evaluasi kemajuan terapi pada pada kedua kasus pasien NPB kronik yang diperoleh dari hasil observasi dan interview selama proses Cognitive Behavior Therapy (CBT), yaitu; (1) Sesi Identification, (2) Sesi Psychoeducational. (3) Sesi Automatic Thought, (4) Sesi Cognitive Restructuring, (5) Sesi Problem Soving, dan (6) sesi Times Based Activity Pacing.

Berdasarkan hasil observasi dan interview yang dilakukan pada setiap awal sesi terapi $C B T$, tabel 2 menggambarkan perubahan intensitas penghayatan stres baik secara fisik maupun psikis yang dapat dilaporkan oleh pasien 1 (G) selama mengikuti seluruh proses terapi $C B T$ dari awal sampai dengan akhir proses terapi.

Hasil observasi dan interview yang dilakukan pada setiap awal dari sesi terapi CBT, tabel 3 menggambarkan perubahan intensitas penghayatan stres baik secara fisik maupun psikis yang dapat dilaporkan oleh pasien 2 (D) selama mengikuti seluruh proses terapi CBT dari awal terapi sampai dengan akhir proses terapi.

Tabel 1

\section{Sasaran Terapi}

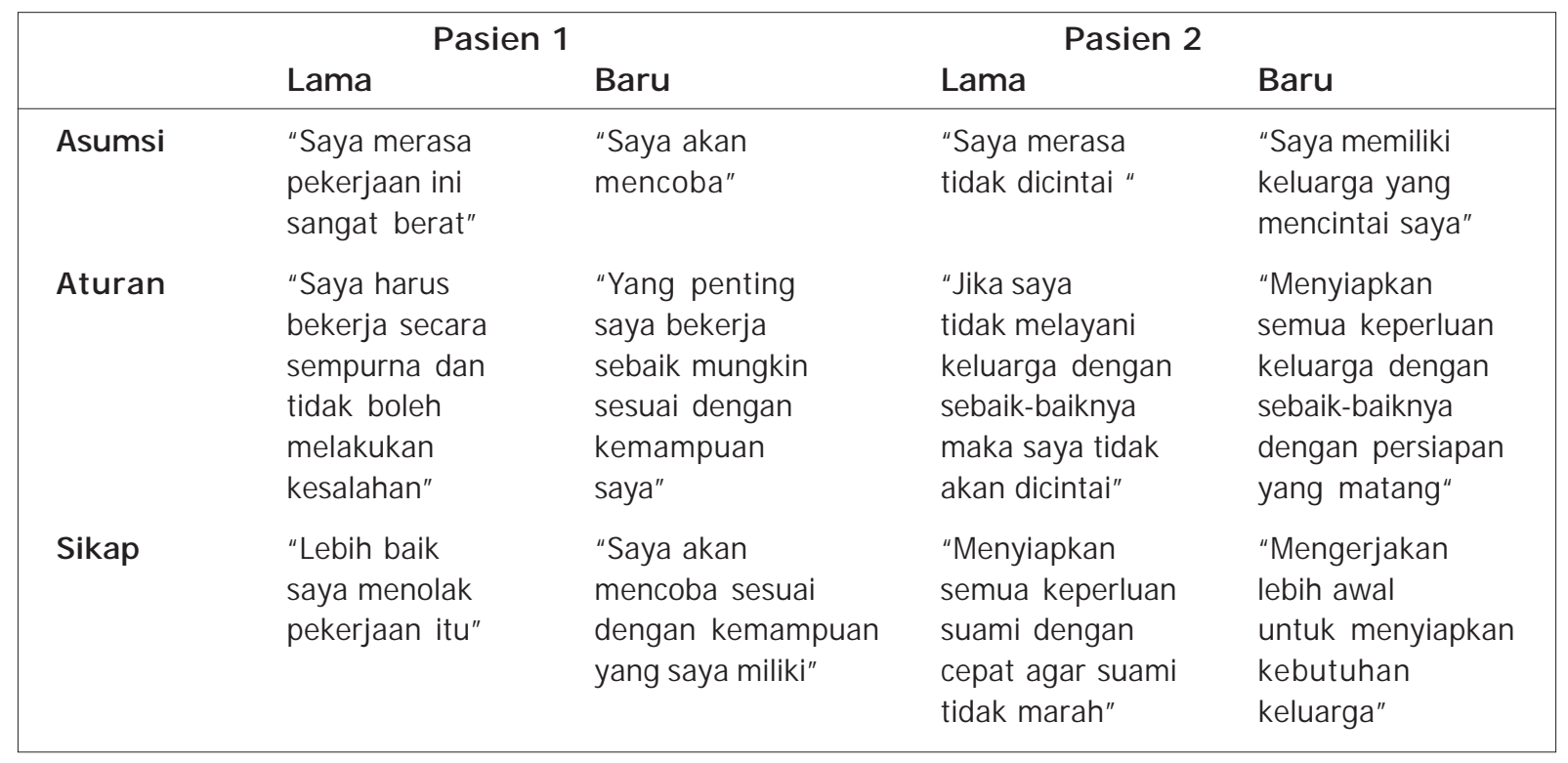


Tabel 2

Evaluasi Gambaran Psikis dan Fisik pada Kasus 1

\begin{tabular}{|c|c|c|c|c|c|c|c|}
\hline & \multirow[t]{2}{*}{ I NDI KATOR } & \multirow[b]{2}{*}{$\mathbf{1}$} & \multicolumn{4}{|c|}{ EVALUASI SESI } & \multirow[b]{2}{*}{6} \\
\hline & & & 2 & 3 & 4 & 5 & \\
\hline \multirow[t]{6}{*}{ Fisiologis } & $\begin{array}{l}\text { Denyut jantung } \& \text { pernapasan } \\
\text { meningkat }\end{array}$ & $X$ & $X$ & $X$ & - & - & - \\
\hline & Ketegangan otot tubuh & $x$ & $x$ & $x$ & $x$ & $x$ & - \\
\hline & Keringat dingin & $X$ & $x$ & - & - & - & - \\
\hline & Pusing & $X$ & $x$ & $X$ & - & - & - \\
\hline & Gangguan pencernaan & $x$ & $x$ & $x$ & - & - & - \\
\hline & Insomnia & - & $x$ & - & - & - & - \\
\hline \multirow[t]{10}{*}{ Psikososial } & Merasa tidak berdaya & $X$ & $x$ & $X$ & $x$ & - & - \\
\hline & Merasa diri tidak berharga & $X$ & $X$ & $X$ & $X$ & - & - \\
\hline & Takut akan nyeri yang sulit & & & & & & \\
\hline & untuk dikendalikan & $x$ & $x$ & $x$ & $x$ & - & - \\
\hline & Cemas & $X$ & $X$ & $x$ & $x$ & - & - \\
\hline & Merasa sulit untuk berkonsentrasi & $x$ & $x$ & - & - & - & - \\
\hline & Terganggunya atensi dalam & & & & & & \\
\hline & aktivitas berpikir & $x$ & - & - & - & - & - \\
\hline & Kurang peduli & $X$ & $X$ & $X$ & $X$ & - & - \\
\hline & Lebih agresif & $X$ & $X$ & $X$ & $x$ & - & - \\
\hline
\end{tabular}

Tabel 3

Evaluasi Gambaran Psikis dan Fisik pada Kasus 2

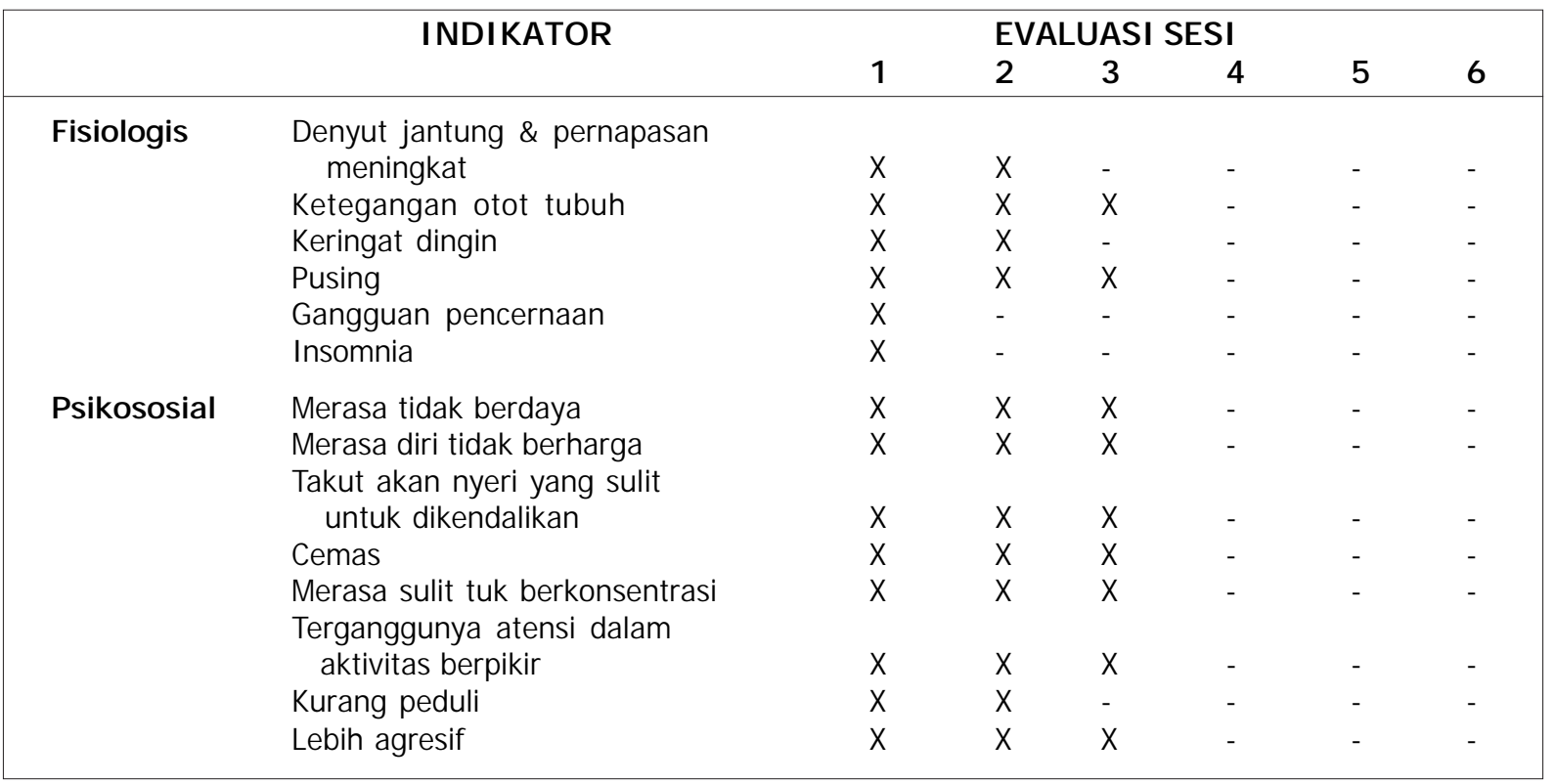

Tabel 4

J enis Distorsi Kognsi Sebelum dan Setelah Pengukuran

\begin{tabular}{|clcc|}
\hline & $\begin{array}{l}\text { JENISDISTORSI } \\
\text { KOGNITIF }\end{array}$ & $\begin{array}{c}\text { PENGUKURAN } \\
\text { AWAL (0-100) }\end{array}$ & $\begin{array}{c}\text { PENGUKURAN } \\
\text { AKHIR (0-100) }\end{array}$ \\
\hline \multirow{2}{*}{ Pasien 1} & Catasthrophizing & 70 & 10 \\
& Emotional Reasoning & 80 & 20 \\
& All Or None Thinking & 80 & 40 \\
Pasien 2 & Personalisasi & 80 & 20 \\
& Mind Reading & 90 & 20 \\
& Jumping to Conclusions & 80 & 20 \\
& Selective Attention & 90 & 30 \\
\hline
\end{tabular}




\section{Distorsi Kognisi Sebelum dan setelah Pengukuran}

Berdasarkan hasil konseptualisasi kognitif atas permasalahan perilaku (terlampir pada lembar lampiran) yang terjaring dalam Daily Thought Record yang memuat kejadian sehari-hari dari kedua pasien NPB kronik, tampak jenis-jenis distorsi kognitif yang dialami oleh kedua pasien sebelumnya, dan kemudian dilakukan pengujian dan intervensi pada setiap distorsi kognitif yang ada, dengan cara menentang (dispute) atas distorsi kognitif yang mereka alami dalam aktivitasnya sehari-hari. Hasilnya dapat dilihat pada Tabel 4.

Berdasarkan hasil intervensi sebagaimana tertera pada Tabel 4, bahwa sebelum dan sesudah intervensi terdapat adanya perubahan yang berarti dalam kaitan dengan distorsi kognisinya.
Jika jenis distorsi kognitif yang dialami oleh pasien 1 (G) digambarkan dalam satu diagram batang secara keseluruhan, maka akan terlihat adanya penurunan distorsi kognitif pada Gambar 1.

Dari setiap intervensi yang dilakukan pada jenis distorsi yang dialami oleh pasien $1(G)$, setiap distorsi kognitif yang dialami dapat dipertentangkan sehingga mengalami penurunan dalam arti dapat berakomodasi pada penurunan tingkat derajat stres yang dialami subjek penelitian. Jenis distorsi kognitif yang dialami oleh pasien 1 (G) adalah catasthrophizing, emotional reasoning, dan all or none thinking.

Adapun distorsi kognitif Catasthrophizing, adalah cenderung berfikir secara catastrophic atau berfikir hanya terfokus pada kemungkinan terburuk dan mudah untuk membuat kesimpulan negatif tanpa data yang mendukung. Pada jenis distorsi

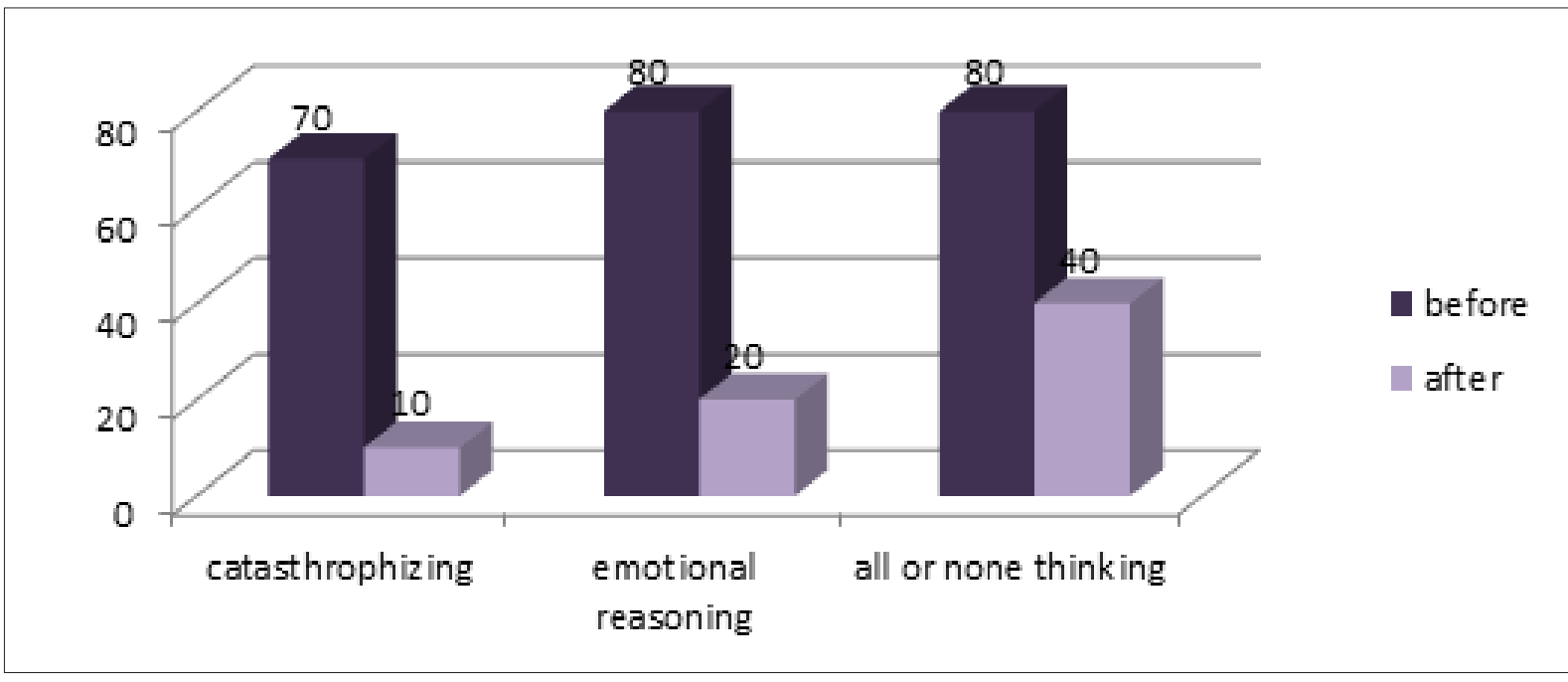

Gambar 1

Distorsi Kognitif pada Kasus 1 (G)

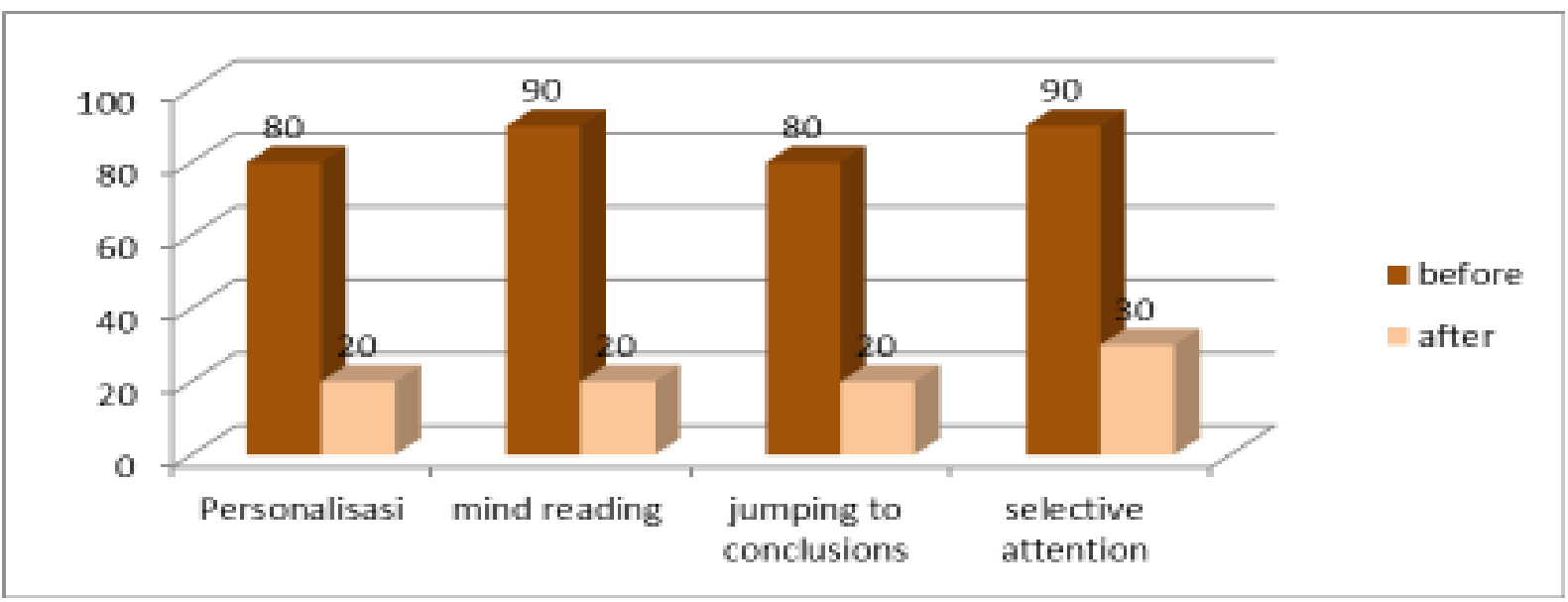

Gambar 2

Distorsi Kognisi padaKasus 2 (D) 
ini ternyata subjek dapat mengurangi derajat catastrophic dari $70 \%$ menjadi $10 \%$. Jenis distorsi yang kedua, emotional reasoning (penalaran emosi) yaitu individu menggunakan emosinya sebagai bukti untuk pembenaran apa yang dikehendakinya. Penalaran emosional iniakan menyesatkan, karena perasaan individulah yang menjadi cermin pemikiran dan keyakinannya, bukan kondisi yang sebenarnya. Dari hasil penelitian ternyata subyek dapat mengurangi persepsi distorsi kognitif dari sebelumnya $80 \%$ menjadi $20 \%$. Jenis distorsi kognitif ketiga adalah all or none thinking, pemikiran ini mengarah pada kecenderungan individu untuk mengevaluasi kualitas pribadi diri sendiri secara ekstrim dalam kategori 'hitam atau putih.' Pemikiran 'bila saya tidak begini maka saya tidak bisa berbuat apaapa." Pemikiran ini merupakan dasar dari sikap perfeksionisme yang berlebihan dan menuntut kesempumaan. Pada hasil penelitian ini terjadi penurunan distorsi kognitif dari skala $80 \%$ menjadi $40 \%$. Jika jenis distorsi kognitif yang dialami oleh pasien 2 (D) digambarkan dalam satu diagram batang secara keseluruhan, berdasarkan data dalam tabel maka akan terlihat adanya penurunan distorsi kognitif.

Dari setiap intervensi yang dilakukan pada jenis distorsi yang dialami oleh pasien 2 (D), distorsi kognitif yang dialaminya adalah personalization, mind reading, jumping to conclusions, dan selective attention. Personalization adalah Individu merasa bertanggungjawab atas peristiwa negatif

Tabel 5

Evaluasi Tahap Problem solving

\begin{tabular}{|lll|}
\hline & Pasien 1 & Pasien2 \\
\hline Core belief lama & Saya tidak mampu & Saya tidak dicintai \\
$\begin{array}{l}\text { Seberapa besar anda yakin akan core } \\
\text { belief lama anda saat ini? }(0 \%-100 \%)\end{array}$ & $40 \%$ & $30 \%$ \\
Paling besar kamu yakini? (0\%-100\%) & $50 \%$ & $55 \%$ \\
Paling kecil kamu yakini? (0\%-100\%) & $40 \%$ & $45 \%$ \\
Keyakinan baru & $\begin{array}{l}\text { "Saya mampu dalam hal } \\
\text { tertentu, tidak mesti mampu }\end{array}$ & $\begin{array}{l}\text { "Saya memiliki keluarga } \\
\text { dalam semua hal" } \\
\text { dengan segala kelabihan } \\
\text { dan kekurangan saya" }\end{array}$ \\
$\begin{array}{l}\text { Berapa besar kamu yakin atas } \\
\text { keyakinan baru kamu? (0\%-100\%) }\end{array}$ & $80 \%$ & $90 \%$ \\
\hline
\end{tabular}

Tabel 6

Bukti yang Membantah Keyakinan Lama dan Mendukung Keyakinan Baru

\begin{tabular}{|c|c|}
\hline Pasien 1 & Pasien 2 \\
\hline $\begin{array}{l}\text { Kalau saya bekerja dengan sepenuh hati semua } \\
\text { pekerjaan dapat diselesaikan dengan baik } \\
\text { Saya tidak pernah bekerja setengah-setengah } \\
\text { Mungkin orang-orang memang sedang sibuk } \\
\text { dengan pekerjaannya masing-masing sehingga } \\
\text { tidak dapat membantu pekerjaan saya } \\
\text { Jika saya menyampaikan dengan tegas tentang } \\
\text { kesulitan saya dalam mengerjakan tugas } \\
\text { biasanya atasan mau mempertimbangkan alasan } \\
\text { saya } \\
\text { Jika pekerjaan ini tidak saya anggap sebagai } \\
\text { beban biasanya rasa nyeri di bagian pinggang } \\
\text { tidak terlalu terasa }\end{array}$ & $\begin{array}{l}\text { Kalau saya sudah menyiapkan sarapan pagi } \\
\text { lebih awal biasanya suami mau membawanya. } \\
\text { Suami saya ternyata tidak } 100 \% \text { tidak } \\
\text { mengerti saya } \\
\text { Pada saat saya bisa menikmati kegiatan yang } \\
\text { saya lakukan, rasa nyeri biasanya akan } \\
\text { berkurang } \\
\text { Kalau saya dapat lebih bersantai (sambil } \\
\text { menonton TV), nyeri yang terasa agak lebih } \\
\text { ringan } \\
\text { Kalau saya bersikap baik dengan suami dia akan } \\
\text { baik dengan saya } \\
\text { Kalau anak diberikan pengertian biasanya dia } \\
\text { mau menurut. } \\
\text { Bila saya bertanya dengan lembut pada suami } \\
\text { biasanya dia mau bercerita tentang masalahnya }\end{array}$ \\
\hline
\end{tabular}


yang terjadi, walaupun sebenarnya peristiwa bukan merupakan kesalahan dirinya. Dari hasil penelitian menunjukkan distorsi kognitif pada personalization terjadi penurun dari $80 \%$ menjadi $20 \%$. Kemudian untuk distorsi mind reading (membaca pikiran orang lain), yaitu seseorang merasa bahwa dia mengetahui apa yang dipikirkan orang lain tanpa memiliki bukti-bukti yang cukup kuat dari apa yang dipikirkannya. Hasil penelitian membuktikan bahwa terjadi penurunan distorsi kognitif adalah dari $90 \%$ menurun menjadi $20 \%$. Ketiga distorsi kognitif yang terajadi adalah jumping to conclusions yaitu menerima interpretasi berdasarkan diri sendiri (arbritary) tanpa evaluasi yang rasional dari kemungkinan-kemungkinan yang lain. Hasil penelitian menunjukkan terdapat perubahan dari distorsi kognisi $80 \%$ berkurang menjadi 20\%. Untuk distorsi kognitif terakhir yang dialami oleh subjek adalah selective attention, yaitu secara selektif memperhatikan aspek yang negatif dari suatu situasi dan mengabaikan setiap hal-hal positif, adapun distorsi kognitif yang terjadi menurun dari $90 \%$ menjadi $30 \%$.

\section{Evalusi Tahap Problem Solving}

Tindak lanjut dalam tahap ini, adalah mengevaluasi tentang kemampuan problem solving dari kedua kasus yang dapat dilihat pada Tabel lembar kerja tentang Core Belief.

Berdasarkan Tabel 5 tampak bahwa keyakinan lama atas core belief negatif yang dialami pasien mengalami penurunan rating setelah munculnya keyakinan baru sebagai akibat dari intervensi Cognitive Behavior Therapy.

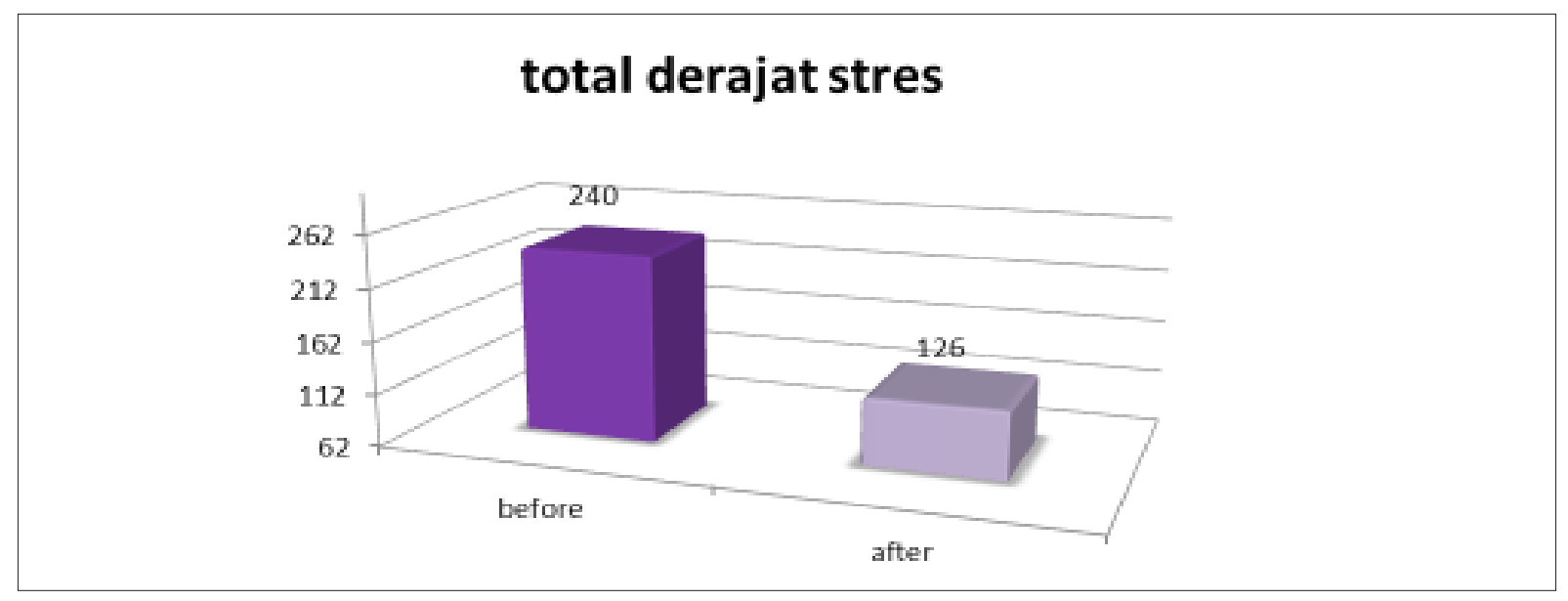

Gambar 3

Indeks Derajat Stres Pasien 1 (G)

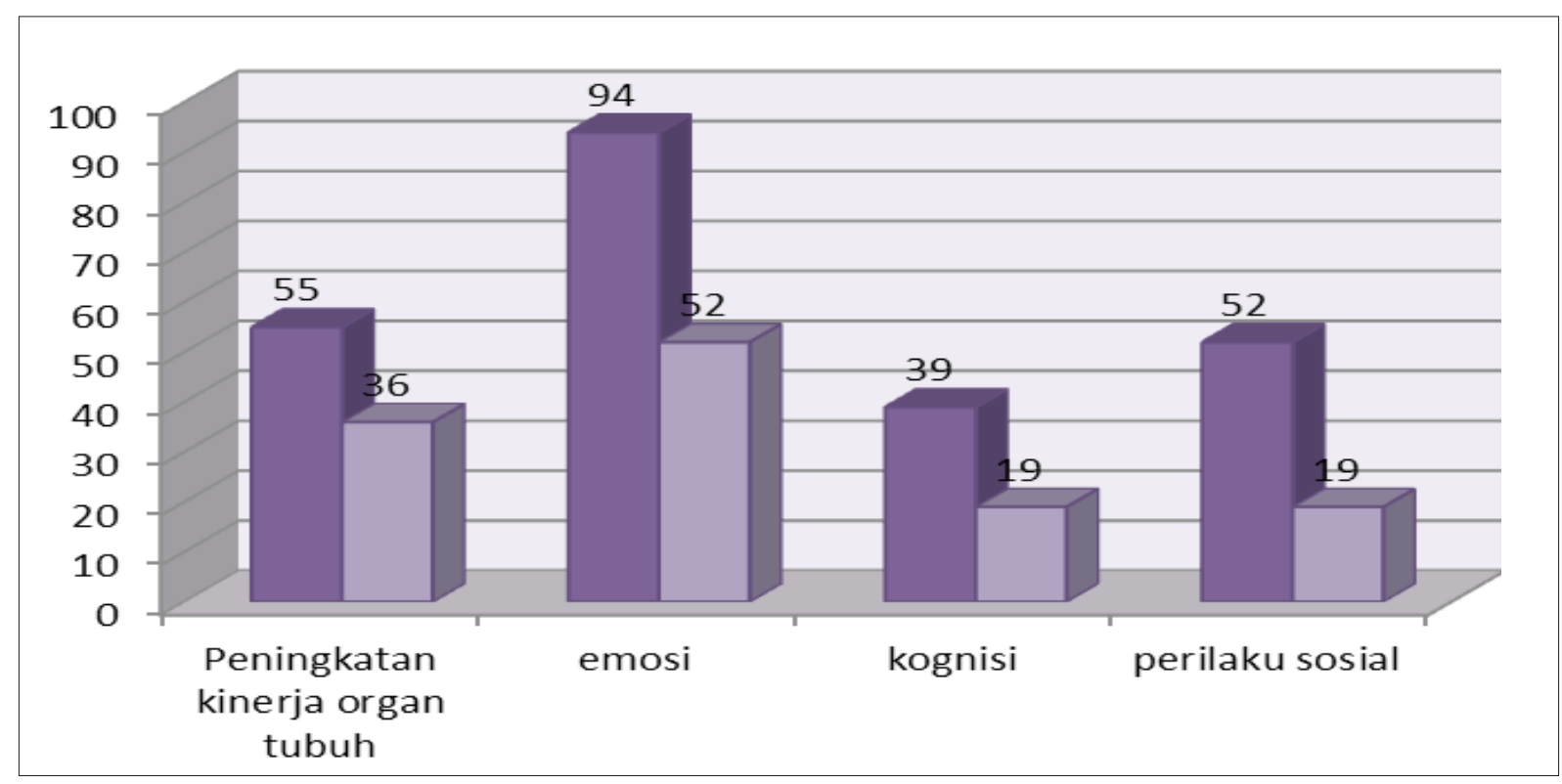

Gambar 4

Perubahan Derajat Stres pada Pasien 1 (G) 


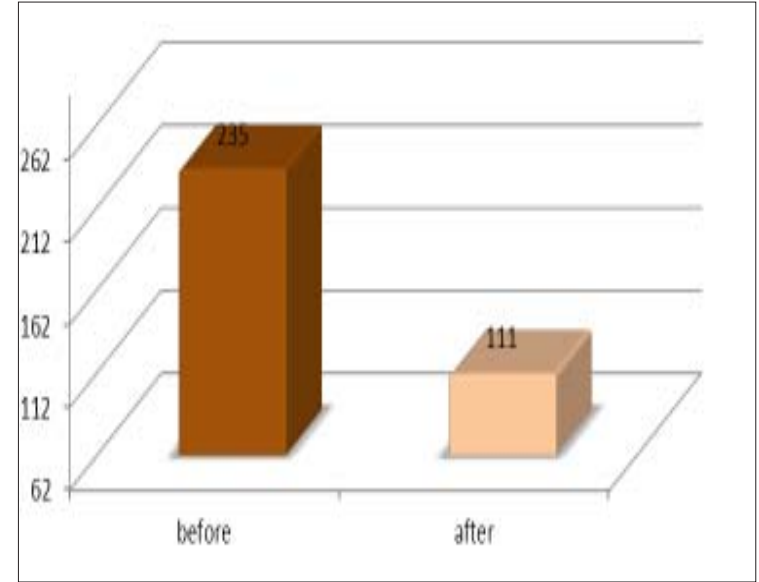

Gambar 5

Indeks Derajat Stres Pasien 2 (D)

\section{Indeks Derajat Stres}

Berikut dipaparkan mengenai perubahan derajat stres pada pasien $1(G)$ dan pasien 2 (D) berdasarkan pada hasil pengukuran pretest sebelum intervensi $C B T$ dan pengukuran setelah postest yang diberikan, yaitu satu minggu setelah pertemuan terakhir CBT (pertemuan ke 7) diperoleh gambaran pada gambar 3.

Berdasarkan hasil pengukuran derajat stres pada grafik 3 diatas diperoleh gambaran bahwa terdapat penurunan derajat stres sesudah diberikan intervensi Cognitive Behaviour Therapy. Kondisi ini terlihat dari hasil pengukuran pada pasien 1 (G) dimana diperoleh skor derajat stres pada awalnya sebesar 240 dan pada pengukuran kedua setelah pemberian intervensi $C B T$ mengalami penurunan skor menjadi 126 . Berdasarkan norma kriteria dari alat ukur derajat stres, hal ini menunjukkan bahwa penurunan derajat stres pada pasien 1 (G) bergerak dari derajat stres "tinggi" menuju derajat stres "moderat rendah" sebagai akibat dari intervensi terhadap distorsi kognitifnya.

Gambaran yang lebih jelas mengenai perubahan derajat stres pada pasien 1 (G) dapat dilihat dalam gambar 4.

Hasil pengukuran pada seluruh aspek dari derajat stres, yaitu aspek peningkatan kinerja organ tubuh, aspek emosi, aspek kognisi, dan aspek perilaku sosial menunjukkan penurunan skor yang cukup signifikan. Pada aspek peningkatan kinerja organ tubuh penurunan skor bergerak dari kategori derajat stres "tinggi" menuju derajat stres "moderat rendah", aspek emosi bergerak dari kategori derajat stres "tinggi" menuju derajat stres "moderat rendah", aspek kognitif bergerak dari kategori derajat stres "tinggi" menuju derajat stres "moderat rendah" dan aspek perilaku sosial bergerak dari kategori derajat stres "tinggi" menuju derajat stres "rendah".

Berdasarkan hasil pengukuran derajat stres pada gambar 5, diperoleh gambaran bahwa terdapat penurunan derajat stres sesudah diberikan intervensi Cognitive Behaviour Therapy. Kondisi ini terlihat dari hasil pengukuran awal pada pasien 2 (D) dimana diperoleh skor derajat stres sebesar 235 dan pada pengukuran kedua setelah pemberian intervensi $C B T$ mengalami penurunan skor menjadi 111. Berdasarkan norma kriteria dari alat ukur derajat stres, hal ini menunjukkan bahwa penurunan derajat stres pada pasien 2 (D) bergerak dari derajat stres "tinggi" menuju derajat

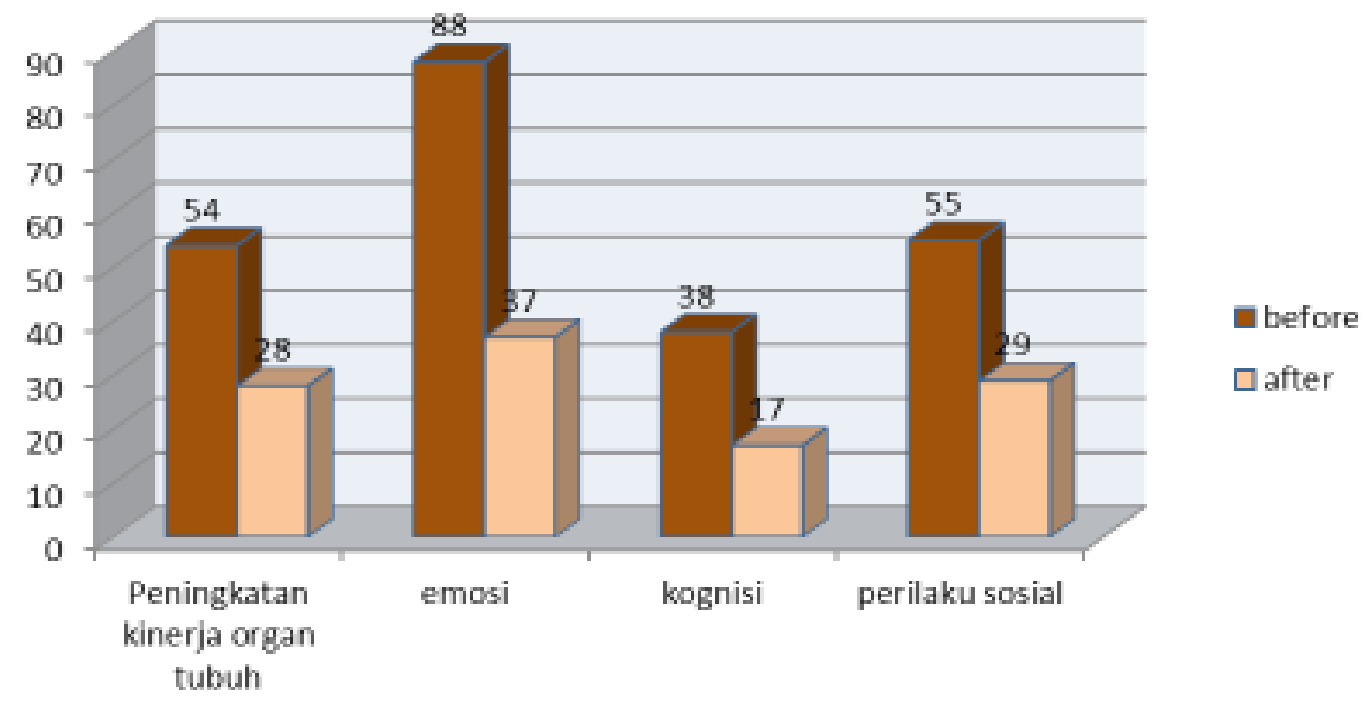

Gambar 6

Perubahan Derajat Stres pada Pasien 1 (G) 
stres "moderat rendah" sebagai akibat dari intervensi terhadap distorsi kognitif yang dialami oleh pasien D yang berakomodasi pada menurunnya derajat stres.

Gambaran yang lebih jelas mengenai perubahan derajat stres pada pasien 1 (G) dapat dilihat dalam gambar 6 .

Hasil pengukuran pada seluruh aspek dari derajat stres, yaitu aspek peningkatan kinerja organ tubuh, aspek emosi, aspek kognisi, dan aspek perilaku sosial menunjukkan penurunan skor yang cukup signifikan. Pada aspek peningkatan kinerja organ tubuh penurunan skor bergerak dari kategori derajat stres "tinggi" menuju derajat stres "moderat rendah," aspek emosi bergerak dari kategori derajat stres "tinggi" menuju derajat stres "rendah", aspek kognitif bergerak dari kategori derajat stres "tinggi" menuju derajat stres "rendah" dan aspek perilaku sosial bergerak dari kategori derajat stres "tinggi" menuju derajat stres "moderat rendah."

Pada kedua kasus ini, dapat disimpulkan bahwa nyeri punggung bagian bawah kronik tidak saja hanya disebabkan oleh aspek fisik semata, namun lebih dipengaruhi pikiran-pikiran irrasional (distorsi kognitif) kedua pasien NPB kronik. Distorsi kognitif yang mereka miliki sangat mempengaruhi cara mereka dalam berespon terhadap stimulus dari lingkungannya. Pada kedua kasus tergambarkan bahwa distorsi kognitif yang ada mengarahkan nyeri digunakan sebagai respon dari situasi stres yang memunculkan konsekuensi, baik positif maupun negatif. Konsekuensi positif inilah yang memertahankan nyeri sehingga berkembang menjadi kronik.

Penerapan CBT sangat efektif dalam menangani pasien NPB kronik karena dapat membantu pasien untuk mengidentifikasikan pikiran-pikiran irrasionalnya, sehingga pasien dapat mengenali faktor-faktor apa saja yang terkait dengan stres yang dapat mempengaruhi peningkatan intensitas nyerinya. Pasien pun dapat mempelajari teknik-teknik bagaimana menangani stres, baik ketika intensitas nyeri meningkat, maupun sebelum nyeri terjadi.

Dari hasil pengukuran pada kedua kasus NPB kronik menunjukkan bahwa CBT berpengaruh secara efektif dalam menurunkan distorsi kognitif yang diikuti oleh penurunan derajat stres pada kedua kasus pasien NPB kronik.

\section{Simpulan dan Saran}

Berdasarkan hasil analisis dan pembahasan dapat disimpulkan bahwa Cognitive Behavior Therapy efektif untuk menurunkan derajat stres pada pasien penderita gangguan nyeri punggung bagian bawah kronis. Penurunan derajat stres tersebut disebabkan oleh karena terjadinya perubahan pemikiran dari irrasional ke pemikiran rasional. Seperti halnya apa yang ditemukan pada pasien $\mathrm{G}$ yang tadinya mengalami distorsi kognitif pada aspek catasthrophizing, emotional reasoning, dan all or none thinking, setelah terapi gejala itu menurun secara drastis. Demikian pula pada pasien D yang awalnya menunjukkan adanya gejala distorsi pada aspek personalization, mind reading, jumping to conclusions, dan selective attention, setelah terapi terjadi penurunan drastis, dan berkembang menjadi lebih rasional.

Dalam memanfaatkan Cognitive behavior therapy khususnya untuk menurunkan derajat stres, sebaiknya bagi peneliti yang tertarik untuk mengembangkan treatment ini perlu terlebih dahulu memeriksa secara saksama tentang pikiran irrasional yang mempengaruhi distorsi kognitifnya, serta peneliti juga perlu mempertimbangkan tentang seberapa besar pengaruh faktor sosial budaya turut memberi kontribusi terhadap pikiran-pikiran irrasionalnya. Oleh karena itu disarankan bagi peneliti lain yang tertarik mengembangkan teknik ini, perlu memerhatikan setiap penurunan distorsi kognitifnya secara periodik dalam penelitiannya, baik secara kuantitatif maupun secara kualitatif. Selain itu ada baiknya peneliti lainnya dapat memasukkan pengaruh faktor sosial budaya apa saja yang ada di I ndonesia yang diperkirakan dapat memengaruhi dan atau menghambat keberhasilan terapi. Sehingga dengan demikian diharapkan para pengguna terapiini dapat lebih akurat dalam membantu keberhasilan klien untuk mengatasi masalahnya, sesuai dengan latar belakang sosial budaya yang diketahui dan diyakininya.

Sedangkan untuk kepentingan praktis, dalam menggunakan Cognitive Behavior Therapy sebaiknya terapis perlu senantiasa menyadarkan klien tentang kesediaan maupun komitmennya untuk tetap melaksanakan keseluruhan terapi sesuai dengan kontrak yang disepakati. Karena faktor kesediaan dan komitmen untuk setia mengikuti terapi merupakan faktor penentu keberhasilan terapi.

Implikasi lebih lanjut dari model terapi ini, khususnya bagi kehidupan sosial dan pembangunan masyarakat di Indonesia adalah untuk melatih dan mengembangkan kemampuan sosial individu agar dapat bersikap rasional dan realistis dalam menghadapi lingkungan sosialnya. Oleh karena itu, model terapi ini sesungguhnya dapat disosialisasikan dan dikembangkan secara lebih luas untuk meningkatkan kesehatan mental masyarakat. Untuk mendukung keberhasilan Cognitive Behavior Therapy untuk meningkatkan kesehatan mental masyarakat, sebaiknya teknik terapi ini sudah disesuaikan dengan kondisi sosial budaya masyarakat Indonesia yang mengarah pada kondisi sosial budaya masyarakat dengan ciri 
UMAR YUSUF, DKK. Efektivitas “Cognitive Behavior Therapy” terhadap Penurunan Derajat Stress

kolektivitas dan kehidupan gotong royong.

\section{Daftar Pustaka}

Cox, Tom, (1978). Stress. London: MacMilan Press Ltd.

Hatta, Ilmi. (2013). Pengaruh Group Counseling terhadap self Regulation pecandu Napza pada Jurnalis Telivisi. Mimbar, Jurnal Sosial dan Pembangunan. Volume 29. No 1. Bandung: P2U LPPM Unisba.

Lazarus, R.S., and Folkman., (1984). Stress Appraisal and Coping. Springer New York: Publishing Company.

Otis, J.D. (2007). Managing Chronic Pain: A Cognitive-Behavioral Approach Workbook. New York: Oxford University Press.

Oemardi,A. Kasandra., (2003). Pendekatan Cognitive Behavior dan Psikoterapi. Creative Me- dia, Jakarta

Sarafino, Edward P., (1990). Health Psychology: Biopsychosocial Interactions-2nd ed. New York: John Wiley \& Sons, Inc.

Thorn, B.E. (2004). Cognitive Therapy for Chronic Pain. New York: The Guilford Press.

Turk, D.C. (2002). A Cognitive Behavioral Perspective on Treatment of Chronic Pain Patients. Dalam Turk, D.C. \& Gatchel, R.J . (penyunting). Psychological Approach to Pain Management: A Practicioner's Handbook 2nd ed, hal 138 158. New York: Guilford Press.

Turk, D.C. \& Gatchel, R.J . (2002) (penyunting). Psychological Approach to Pain Management: $A$ Practicioner's Handbook 2nd ed. New York: Guilford Press.

Yusuf. Umar. \& Patrisia Reisa (2011). Pengaruh Terapi Cognitive Behavior Therapy terhadap Kontrol diri pada residivis. Jurnal Intervensi Psikologi Vol 3. No 2 Yogyakarta. 